\title{
ARTYKUŁY
}

Klio. Czasopismo poświęcone dziejom Polski i powszechnym PL ISSN 1643-8191, t. 26 (3)/2013, s. 117-139

(c) (1) $\Theta$

DOI: http://dx.doi.org/10.12775/KLIO.2013.035

JOANNA WOJDON

(Wrocław)

\section{Kampania wrześniowa $w$ polskich i zagranicznych podręcznikach szkolnych}

\section{Świat}

7 okazji pięćdziesiątej rocznicy wybuchu drugiej wojny światowej baCdania nad sposobem przedstawienia kampanii wrześniowej w zagranicznych podręcznikach do nauczania historii prowadził Adam Suchoński ${ }^{1}$. Swoją kwerendą objął książki z 58 krajów świata, stwierdzając, że Polska była w nich wszystkich obecna, nawet jeśli informacja miała tylko charakter krótkiej wzmianki. Nie chcąc powtarzać tych badań, ograniczyłam się do podręczników, które ukazały się już w XXI w., głównie w krajach europej-

${ }^{1}$ A. Suchoński, Wrzesień 1939 roku w międzynarodowych podręcznikach do nauczania historii, [w:] Polski wrzesień 1939 r. - wojna na dwa fronty. Pamiętnik Konferencji. Materiaty z Międzynarodowej Konferencji Naukowej, red. A. Felchner, Piotrków Trybunalski 1999 , s. 385-400. 
skich oraz w Stanach Zjednoczonych ${ }^{2}$. Celem analizy było sprawdzenie, jak przez te lata zmienił się obraz polskiego Września.

W dalszym ciągu można stwierdzić, że w kontekście wybuchu drugiej wojny światowej Polska zawsze występuje w książkach do historii. Czasami, choć rzadko, jest to tylko jednozdaniowa wzmianka, że druga wojna światowa rozpoczęła się od ataku niemieckiego na Polskę 1 września 1939 r. [GB-6, 9; bardzo lakoniczne są też RUS-5 i 7]³. Data ta, czasem ograniczona tylko do miesiąca, występuje także we wszelkich tabelach, mapach i osiach czasu, kończąc drogę do wojny (rozpoczynającą się od początku lat trzydziestych [np. GB-7; F-2; NL-1] czy wręcz od traktatu wersalskiego [USA-4; GB-5]) lub zaczynając przebieg konfliktu zbrojnego (rzadziej $\mathrm{w}$ innych przedziałach czasowych).

Charakteryzując bliżej początek drugiej wojny światowej, podręczniki zagraniczne najczęściej przywołują albo rozkaz Adolfa Hitlera, wyznaczający datę ataku na Polskę [CS-5; A-1; SRB-1], albo prowokację gliwicką (przeważnie pojawia się nazwa Gleiwitz, choć Czesi podają także nazwę polską [CS-2, 3]) mającą usprawiedliwić podjęcie działań zbrojnych - tu relacje różnią się w szczegółach, natomiast zawsze jest podkreślane, że była to niemiecka akcja, mająca stworzyć pretekst do podjęcia działań zbrojnych bez wypowiedzenia wojny [IRL-1, 2; GB-2; CS-2, 3, 5; D-1, 2, 3, 4; A-1; HR-1, 2]. Podręczniki czeskie i niemieckie przywołują także godzinę rozpoczęcia działań zbrojnych (4:45) [CS-2, 3, 5; D-3]. Przytaczana bywa także okolicznościowa mowa Hitlera w Reichstagu [D-3; A-1]. Jeden

${ }^{2}$ Kompletna kwerenda musiałaby być niezwykle obszerna - w większości krajów Europy Zachodniej nie istnieje urzędowy system dopuszczania podręczników do użytku szkolnego, a decyzję o wyborze konkretnego tytułu spośród dostępnych na wolnym rynku podejmują nauczyciele i/lub rodzice (por. L. Cajani, History textbooks between teachers' freedom and State control, materiały z Konferencji Międzynarodowego Stowarzyszenia Dydaktyki Historii, Brunszwik 2009). Liczba około 50 pozycji, z którymi się zapoznałam, pozwala już jednak na sformułowanie pewnych wniosków. Bardzo dziękuję Pani Renacie Gröger-Kani z Międzynarodowego Instytutu Badań nad Podręcznikiem w Brunszwiku za bezcenną pomoc w przeprowadzeniu kwerendy.

${ }^{3} \mathrm{~W}$ nawiasach kwadratowych zamieszczam informacje o przytaczanych podręcznikach według schematu: [kraj, numer podręcznika z danego kraju]. Ich pełna lista znajduje się w bibliografii na końcu tekstu. Ponieważ ustępy poświęcone kampanii wrześniowej są zwykle krótkie lub bardzo krótkie, także numery stron znajdują się w bibliografii. 
z podręczników czeskich odnotowuje, że do agresji niemieckiej na Polskę przyłączyła się Słowacja [CS-1].

Już Suchoński wskazywał, że starsze podręczniki zachodnie pisały jeszcze o uporze Polski wobec roszczeń niemieckich dotyczących Gdańska i „polskiego korytarza” jako o przyczynie wojny, czyniąc władze Rzeczpospolitej niejako współodpowiedzialne za wybuch konfliktu. Równocześnie zauważał, że dało się zaobserwować odchodzenie od tego toku rozumowania i wskazywanie na wyłączną odpowiedzialność Hitlera oraz jego planów podboju świata ${ }^{4}$. Ta tendencja zdaje się dzisiaj zdecydowanie dominować [np. GB-1; CS-2, 3; SRB-1]. Wspomina się czasem o żądaniach niemieckich wobec Polski [F-1; HR-1] (najwięcej zrozumienia dla nich wydają się okazywać podręczniki brytyjskie) i podkreśla się niechęć Polski do kompromisów z Niemcami [GB-2, 4, 7, 8], jednak postawa Polaków budzi raczej zrozumienie i uznanie autorów książek szkolnych. Wskazują oni, że doświadczenia innych krajów musiały przekonać stronę polską, iż układy z Niemcami bywają fatalne w skutkach, a żądania niemieckie były pogwałceniem przyrzeczeń Hitlera z Monachium, i Europa musiała zakończyć politykę ustępstw, jeśli chciała zachować swą godność oraz pozycję w dalszych stosunkach z III Rzeszą [USA-2; GB-4; GB-5; RO-1].

Trzy inne wydarzenia - oprócz niemieckiego ataku na Polskę - z września 1939 r. występujące w zagranicznych podręcznikach dość często to:

- wypowiedzenie wojny Niemcom przez Wielką Brytanię i Francję [IRL-1 i 2; GB-2; D-1, 4; CS-4; RUS-6, 8];

- sowiecka agresja na Polskę [GB-2; GB-8; GB-4; USA-1; D-1, 2; F-1; A-1; SRB-1; CS-4];

- zakończenie niemieckich działań zbrojnych w kampanii wrześniowej.

Brytyjska i francuska reakcja na atak niemiecki jest ukazywana jako wydarzenie, które przekształciło lokalną polsko-niemiecką wojnę w konflikt światowy [USA-5; CS-2; SRB-1], a tym samym przekreśliło nadzieje Hitlera na wojnę szybką i łatwą [GB-5, 8; I-2]. Zaznacza się często, że było to wypełnienie zobowiązań sojuszniczych [GB-8; USA-3; CS-5; D-2, 3;

\footnotetext{
${ }^{4}$ A. Suchoński, Wrzesień 1939 roku, s. 387.
} 
A-1; HR-2; RUS-1] i przypomina się umowy zawarte z Polską przez oba mocarstwa [GB-1] jako koniec polityki appeasement oraz przeciwstawienie układom monachijskim [GB-4; HR-1]. Przytaczane jest ultimatum brytyjskie wobec Niemiec, cytowane są przemówienia Neville’a Chamberlaina [GB-3, 5], reprodukowane tytułowe strony brytyjskiej prasy z początku września donoszące o ataku na Polskę lub o przyłączeniu się Wielkiej Brytanii do wojny [HR-2]. Książki te pomijają natomiast na ogół kwestie militarne, tzn. fakt niepodjęcia przez zachodnich sojuszników działań zbrojnych przeciw Niemcom. Neutralnie o braku tych działań piszą autorzy podręczników z Austrii, Niemiec i Holandii oraz Rumunii [A-1; D-2; D-3; RO-1; NL-1]. Można znaleźć także zagraniczne pozycje, które bierność aliantów usprawiedliwiają ich nieprzygotowaniem do wojny lub zbyt krótkim czasem trwania kampanii (nie zdążyli zorganizować przerzucenia jednostek) [USA-4; GB-5; CS-1; USA-1; GB-2: nie były w stanie ocalić Polski]. Są jednak również podręczniki znacznie bardziej krytyczne [CS-3; SF-1], które piszą o dziwnej wojnie [IRL-1; CS-3; HR-2; RUS-3, 4] czy wojnie siedzącej (Sitzkrieg) [CS-1; LV-1; I-2], czy też wspominają użycie francuskich samolotów do rozrzucania na terytorium Niemiec ulotek [CS-2]. Cytowane są wspomnienia dowódców niemieckich zdziwionych postawą Zachodu [CS-5]. Warto odnotować książkę chorwacką, która dokonuje szczegółowego zestawienia sił Niemiec i zachodnich aliantów na początku drugiej wojny światowej, pokazując, że były one wówczas niemal równe, więc wojna była do wygrania, gdyby tylko Anglia i Francja zechciały przystąpić do walki [HR-1]. Natomiast podręcznik rosyjski propaguje wręcz tezę, że wobec przerzucenia większości sił niemieckich na front wschodni alianci mieli na zachodzie znaczną przewagę, a ocena ich postaw brzmi bardziej oskarżycielsko niż w książkach polskich [RUS-1]:

Gdy 90 dywizji angielsko-francuskich stało naprzeciw 33 dywizji niemieckich na Zachodzie, Niemcy siłami ponad 50 dywizji lądowych rozprawiały się ze znacznie słabszą Polską na Wschodzie.

Niektóre podręczniki zaznaczają dodatkowo, że wraz z Wielką Brytanią w stanie wojny z Niemcami znalazły się też jej dominia: Kanada, Nowa Zelandia, Australia i Indie [CS-3; HR-1, 2]. Wspomina się również 
neutralność USA [CS-3; I-2; [D-4]. Czasami odnotowuje się także wprowadzenie morskiej blokady Niemiec oraz zatopienie jednej z jednostek brytyjskiej marynarki, co jest traktowane jako wstęp do bitwy o Atlantyk [IRL-1; CS-3].

Jeśli chodzi o agresję sowiecką, to najczęściej jest przedstawiana jako realizacja postanowień układu Ribbentrop-Mołotow [CS-5; D-3; HR1]. Przy okazji omawiania tego paktu [np. LT-1] podkreśla się, że ułatwiał Hitlerowi podjęcie decyzji o ataku, gwarantując spokój ze Wschodu [USA-2]. Tajny protokół jest oceniany zdecydowanie negatywnie [USA-5], pojawiły się nawet stwierdzenia o czwartym rozbiorze Polski [HR-2]. Jedynie niektóre podręczniki rosyjskie próbują usprawiedliwiać porozumienie z Niemcami radziecką racją stanu [RUS-1, 5, $7^{5}$ ].

Podkreśla się, że Armia Czerwona zatrzymała się na linii wyznaczonej w tajnym protokole [SF-1; USA-3; IRL-1; CS-3; [I-3]. Wspominana jest wspólna, niemiecko-sowiecka defilada zwycięstwa w Brześciu [RUS-1; LT-1; LV-1], a w podręcznikach rosyjskich - nowy niemiecko-sowiecki układ o przyjaźni i granicach [RUS-2: z zaznaczeniem, że nowe granice były zgodne z kryterium etnicznym i z linią Curzona, co świadczyło o niechęci ZSRR do antagonizowania Anglii i Francji, 3, 4, 5, 6, 8]. Podręcznik czeski przywołuje - z wyraźnie negatywną oceną - oficjalne uzasadnienie Józefa Stalina dla przyłączenia polskich Kresów Wschodnich [CS-2]. W tym miejscu lub podczas omawiania schyłku kampanii wrześniowej niejednokrotnie stwierdza się, że oto Polska (czasem - podkreślając, że po raz kolejny) przestała istnieć jako państwo na mapie świata [USA-3; LT-1; I-2; D-3; F-2; SRB-1]. Książki rosyjskie dość zgodnie powtarzają, że Armia Czerwona wkroczyła (nawet jeśli bez wypowiedzenia wojny) już po ewakuacji (albo ucieczce) władz polskich, gdy losy kampanii były przesądzone [RUS-2, 3, 5, 6, 7, 8], i nie spotkała większego oporu [RUS-1, 2, 6]. Konsekwentnie też stosują nazwę Zachodnia Białoruś i Zachodnia Ukraina na określenie terenów zajętych przez Sowietów [RUS-3, 4, 5, 8].

${ }^{5}$ Choć w jednym z rosyjskich podręczników mówi się, że istnieje też interpretacja obarczająca agresję radziecką winą za polską porażkę w kampanii wrześniowej, ale informacji tej zaprzecza się, stwierdzając, że oddziały niemieckie wciąż posuwały się na wschód i nie było gwarancji, że zechcą dotrzymać umów ze Związkiem Radzieckim [RUS-7]. 
Podręczniki różnią się w kwestii umiejscowienia 17 września w toku kampanii wrześniowej, co wiąże się z różnym podejściem do jej trwania. Te najbardziej lakoniczne kwitują walki stwierdzeniem, że Polska została rychło pokonana [GB-8; RUS-3]. Są takie, które utrzymują, że działania zbrojne trwały zaledwie dwa tygodnie, a wkroczenie Armii Czerwonej nastąpiło w zasadzie po ich zakończeniu - jako przypieczętowanie losu Polski [RO-1; SRB-1]. Jedna z książek brytyjskich traktuje inwazję sowiecką i niemiecką całościowo [GB-1]. Inne piszą o trzy- [GB-4], cztero- [CS-2; D-2; A-1: mniej niż cztero-], pięcio- [IRL-1; D-3: mniej niż pięcio-], kilkutygodniowej [USA-4; F-2] lub miesięcznej [HR-1] kampanii, a aktywność Sowietów często przeciwstawiają bierności zachodnich sojuszników Polski. Podręcznik czeski zaznacza, że Armia Czerwona zaatakowała, zanim jeszcze padła Warszawa [CS-3]. Wśród konkretnych wydarzeń kończących działania wojenne w Polsce była podawana kapitulacja Warszawy z datą 28 września [E-1; GB-2: 27 września; RUS-2; RUS-7: 20 (!) września] (można spotkać zdjęcia Hitlera przyjmującego niemiecką defiladę w polskiej stolicy [NL-1; I-2: przyglądający się oddziałom maszerującym do Warszawy, 3]), ale także 5 lub 6 października - kapitulacja ostatnich polskich oddziałów regularnej armii [CS-1; D-2]. Jeden z podręczników podkreśla, że Polska jako państwo nigdy nie skapitulowała, a część armii przedostała się na Węgry i do Rumunii, skąd przeprawiła się na front zachodni [CS-1]. Czasem też wspomina się, że władze polskie udały się na emigrację (błędnie podając, że do Londynu - [LV-1; D-2]).

Czego zagraniczni uczniowie mogą się dowiedzieć o samym przebiegu kampanii? Przede wszystkim bywa ona ilustracją pojęcia wojny błyskawicznej (na ogół z podaniem niemieckiego terminu Blitzkrieg przetłumaczonego na języki narodowe) [USA-5; GB-2; LV-1; LT-1; CS-1, 2, 3; I-2; F-2; SF-1; RO-1; HR-2; RUS-2, 4]. W zasadniczym tekście podręcznika lub na marginesach, w słowniczkach pojęć, w podpisach pod ilustracjami przedstawia się nowoczesność tej strategii, wykorzystanie zdobyczy technologicznych lotnictwa, wojsk pancernych i piechoty zmotoryzowanej [IRL-1 stosuje trójwymiarowy model]. Dość często prezentowane są zdjęcia niemieckich jednostek pancernych przejeżdżających przez Polskę (najczęściej wśród pól), czasem innych pojazdów mechanicznych lub „stukasów” [USA-3; E-1; D-2]. Rzadziej są przywoływane konkretne dane liczbowe 
[USA-4; E-1]. Podręczniki wskazują, że Niemcy stosowali Blitzkrieg także w kolejnych starciach na Zachodzie Europy oraz przeciwko ZSRR [USA-2; IRL-1; D-4; RUS-5].

O wojskach polskich w kampanii wrześniowej na ogół się nie wspomina. W ten sposób widać raczej siłę Niemiec niż słabość Polski (co jest znacznie bardziej uwypuklane w książkach polskich niż zagranicznych), której los wydaje się przesądzony od samego początku i może budzić wspótczucie [GB-4]. Niekiedy odnotowywane jest też bohaterstwo Polaków broniących swojej ojczyzny [LT-1; CS-1, 2, 3, 5; SRB-1; HR-1]. Podręcznik brytyjski wspomina o polskiej armii jako dzielnej, ale przestarzałej i źle zorganizowanej, używającej kawalerii [GB-2], o armii ustępującej Niemcom liczebnością i uzbrojeniem piszą Hiszpanie [E-1], o słabej - Włosi [I-2]. Podręcznik rosyjski podaje proporcje strat: 50 tys. niemieckich, 600 tys. polskich (łącznie z jeńcami) [RUS-4].

Jeśli chodzi o poszczególne epizody kampanii wrześniowej, to w kilku zagranicznych podręcznikach reprodukowane jest zdjęcie niemieckich żołnierzy łamiących polski szlaban, ewentualnie usuwających słup graniczny - moment rozpoczęcia drugiej wojny światowej [I-2; I-3; HR-1]. Pisze się też o odwrocie armii polskiej. W podręczniku czeskim pojawia się również bitwa nad Bzurą [CS-1], w rosyjskim - Hel i Modlin jako pojedyncze ogniska oporu [RUS-7]. Była już mowa o wkroczeniu Armii Czerwonej i o kapitulacji Warszawy [HR-1]. I to w zasadzie wszystko.

Trzy razy tylko znalazłam wzmiankę o losie polskich jeńców wojennych, którzy dostali się do niewoli [LV-1; RUS-7, 8] - co postulował w swym opracowaniu Adam Suchoński. W tym zakresie chyba niewiele się więc zmieniło. Czasem wspominane są ciężkie warunki okupacji na ziemiach polskich [E-1; CS-2; A-1; HR-1], czasem - Holocaust (w tekście o Holokauście kampania wrześniowa jest jedynie wzmiankowana jako wstęp do eksterminacji Żydów i jako taka autorów nie interesuje [I-1]). Przywoływana jest odezwa Hitlera do niemieckich dowódców przed wkroczeniem do Polski, w której apeluje on o bezwzględność i wykluczenie żalu wobec przeciwnika [I-2]. Na ogół po omówieniu kampanii wrześniowej pisze się albo o dalszych agresywnych poczynaniach Związku Sowieckiego - wojnie północnej z Finlandią (i o wykluczeniu ZSSR z Ligi Narodów w ostatnim akcie tej organizacji) oraz przyłączeniu republik bałtyckich 
[LV-1; CS-5; SRB-1; HR-1; RUS-5, 6], albo o froncie zachodnim: „dziwnej” wojnie zakończonej ofensywą niemiecką w kwietniu 1940 r. [np. USA-3; CS-5; SF-1].

\section{Polska}

A jak wygląda kampania wrześniowa we współczesnych podręcznikach polskich? W tym przypadku baza źródłowa będzie nieco odmienna - nie będę bowiem szczegółowo analizować książek wydanych w latach 1999-2010, a więc do „starej” podstawy programowej. Odwołując się do pewnych wniosków dotyczących tego okresu' ${ }^{6}$, skoncentruję się na podręcznikach aktualnie obowiązujących. W myśl założeń ostatniej reformy systemu edukacji z historią najnowszą zapoznają się wszyscy uczniowie w szkole podstawowej oraz w pierwszej klasie szkół ponadgimnazjalnych. Właśnie podręczniki ponadgimnazjalne z zakresu podstawowego będą przedmiotem rozważań.

Co warte docenienia, we wszystkich analizowanych książkach kampania wrześniowa jest przedstawiana jako wydarzenie rozgrywające się na ziemiach polskich, ale należące do historii powszechnej („Polski wrzesień - początek II wojny światowej" [wyróż. moje - J. W.], jak to zostało ujęte w jednym z podręczników [PL-Stentor]). Niekiedy wręcz jest częścią większego rozdziału dotyczącego działań wojennych w Europie [PL-WSzPWN]. Czasem stanowi odrębną całość, ale w kolejnej odsłonie przedstawiane są wydarzenia europejskie, najczęściej wojna zimowa w Finlandii, a następnie atak hitlerowski na Europę Zachodnią [PL-Stentor]. Dwa spośród polskich podręczników dość tradycyjnie oddzielają jednak „dziwną wojnę” od kampanii wrześniowej i przenoszą ją do odrębnego, „światowego” rozdziału [PL-WSiP; PL-SOP1]. Dawniej nierzadko zdarzało się (nieszczęśliwie), że po kampanii wrześniowej przechodzono do położenia ziem polskich podczas drugiej wojny światowej, wydarzenia z ogólnego teatru wojny opisując

${ }^{6}$ Szczegółowo przedstawiałam je podczas konferencji „Kampania polska 1939 strategia, polityka i społeczeństwo, imponderabilia - pamięć - kultura” zorganizowanej przez Muzeum Historii Polski 16-17 października 2009 r. 
w innych częściach podręczników ${ }^{7}$. Dziś tylko jedna spośród analizowanych książek zamieszcza początki informacji o okupacji i początkach konspiracji od razu w rozdziale o kampanii wrześniowej, ciągnąc je do 1940 r., a deportacje ludności - nawet do 1945 r. [PL-Stentor].

1 września 1939 r. jest najczęściej traktowany jako kluczowa cezura - początek nie tylko nowego rozdziału, ale całej części podręcznika. Mniej i bardziej bezpośrednia droga ku wojnie (w tym appeasement, sojusze, rokowania w lecie 1939 r. i pakt Ribbentrop-Mołotow) należy wówczas do dwudziestolecia międzywojennego, a więc niejako do innej epoki [PLNE; SOP-1]. Niektórzy autorzy decydują się jednak potraktować je jako wstęp do drugiej wojny światowej i zamieszczają już w części „wojennej” [PL-WSiP; PL-Stentor; PL-WSzPWN]. Interesujące byłyby badania empiryczne nad wpływem, jaki przypisanie zagadnienia do tego lub innego działu ma na tok rozumowania i świadomość uczniów (którzy tak często uczą się od sprawdzianu do sprawdzianu, zamkniętego właśnie końcem działu tematycznego).

Z wydarzeń 1 września najczęściej wymieniany jest atak na Westerplatte [PL-NE; PL-WSzPWN; PL-SOP2] oraz obrona poczty gdańskiej. Niektóre podręczniki wspominają, że jako pierwsze polskie miasto zaatakowany został Wieluń [PL-WSiP; PL-Stentor; PL-SOP1; PL-WSzPWN - przedstawia Wieluń na zdjęciu], ale i tak przechodzą następnie do Westerplatte, a symbolem 1 września pozostaje pancernik Schleswig-Holstein. Rzadziej niż w poprzednich latach pojawia się postać majora Henryka Sucharskiego [PL-SOP2], raz towarzyszy mu także kapitan Franciszek Dąbrowski [PL-NE]. Podkreśla się bohaterstwo pracowników poczty w Gdańsku oraz

7 Np. J. Wendt, Historia III [gimnazjum],Wydawnictwo M. Rożak, Gdańsk 2000; K. Starczewska et al., Świat wspótczesny. Od wybuchu II wojny światowej. Klasa III. Częś́ II, Wydawnictwo Szkolne PWN, Warszawa 2002; M. Gładysz, Historia III. Czasy wspótczesne. Podręcznik dla klasy trzeciej liceum i technikum. Zakres podstawowy i rozszerzony, GWO, Gdańsk 2004 (najpierw przedstawia wydarzenia globalne, potem wraca do kampanii wrześniowej i zajmuje się ziemiami polskimi); A. Garlicki, Historia 1939-2001. Polska i świat. Podręcznik dla liceów ogólnoksztatcąych, liceów profilowanych i techników. Ksztatcenie $w$ zakresie podstawowym i rozszerzonym, Wydawnictwo Naukowe Scholar, Warszawa 2002. 
determinację obrońców Westerplatte i załogi Helu. Sporadycznie mowa jest także o prowokacji gliwickiej [PL-Stentor; PL-NE].

Jeśli chodzi o kolejne wydarzenia kampanii, to należy zauważyć zdecydowane odejście od karuzeli bitew i nazwisk, tak typowej dla wcześniejszych opracowań. Tradycyjne ujęcie reprezentuje już chyba tylko podręcznik Wydawnictw Szkolnych i Pedagogicznych, w którym aż roi się od armii, dowódców i starć (tylko na pierwszej stronie mamy ponad 20 różnych nazw). Dość obszernie traktuje też temat Nowa Era. Pozostałe książki szczegółowy przebieg kampanii przedstawiają na stosownej mapie - występuje ona we wszystkich analizowanych opracowaniach, czasem towarzyszą jej konkretne polecenia (od prostego odnalezienia miejsc starć zbrojnych, z podziałem na te stoczone z Niemcami i z ZSSR [PL-Stentor; PL-NE; PL-SOP2], przez określenie kierunków uderzenia niemieckiego [PL-WSzPWN; PL-SOP1], po wymagającą większego wysiłku intelektualnego ocenę trudności obrony terytorium II Rzeczypospolitej [PL-SOP1]). Do kanonu bitew pojawiających się w tekście autorskim, poza Westerplatte i Helem, weszły Mokra, Bzura ${ }^{8}$ i obrona Warszawy, a także kończąca kampanię bitwa pod Kockiem. Powszechnie występuje także Wizna określana jako „polskie Termopile” (Wydawnictwo Stentor czyni to nie wprost, przytacza bowiem napis z umieszczonej na miejscu bitwy tablicy pamiątkowej i pyta, do którego starożytnego epitafium tekst ów nawiązuje [PL-Stentor]).

Do kanonu wydarzeń z toku kampanii należy wypowiedzenie wojny Niemcom przez Francję oraz Wielką Brytanię i prowadzona następnie przez te państwa „dziwna wojna” - oceniana zdecydowanie negatywnie przez polskich autorów. Podkreśla się zawiedzione nadzieje Polaków i złamane obietnice aliantów, a w efekcie - osamotnienie Rzeczypospolitej [PL-WSiP; PLStentor; PL-SOP1; [PL-SOP2]. Powszechne są informacje o rozrzucaniu pacyfistycznych ulotek przez francuskie samoloty na terytorium Niemiec [PL-WSiP; PL-WSzPWN; PL-SOP1]. Jeden ze stosownych fragmentów ma wręcz charakter ironiczny:

${ }^{8}$ W podręczniku Wydawnictwa Stentor bitwie nad Bzurą towarzyszy dość rozbudowana infografika, przedstawiająca kolejne fazy bitwy [PL-Stentor]. 
Alianci skupili się zaś na prowadzeniu wojny siedzącej, zwanej też „dziwną wojną", która polegała na zrzucaniu nad państwem niemieckim ulotek propagandowych [PL-NE].

Pacyfizm najwyraźniej nie znajduje zrozumienia u autorów polskich podręczników9 . Fotografia żołnierzy angielskich i francuskich, którzy siedząc w okopie, rozlewają do menażek alkohol [PL-NE], wzbudzi raczej pogardę niż empatię uczniów. Tylko troszkę bardziej neutralny jest podpis:

Gra w karty i koncerty znanych artystów pozwalały francuskim żołnierzom pokonać nudę dziwnej wojny [PL-WSiP].

Wreszcie należy odnotować 17 września i inwazję Armii Czerwonej. Podręczniki różnią się ilością miejsca i szczegółów poświęconych tej części kampanii. Część wymienia konkretne starcia zbrojne, np. obronę Grodna albo bitwę pod Tomaszowem Lubelskim ${ }^{10}$ [PL-WSiP; PL-Stentor; PL-WSzPWN; PL-SOP1], część zaś wspomina ogólnie o walkach prowadzonych przez Korpus Ochrony Pogranicza i niektóre inne jednostki [PL-WSiP; PL-NE; PL-SOP2]. W tym miejscu w jednym z podręczników zostaje też podjęta kwestia żołnierzy wziętych do niewoli, prowadzonych aż do Katynia ${ }^{11}$ [PL-Stentor]. Inne podręczniki tego wątku w ogóle nie podejmują (przenosząc go do rozdziałów poświęconych okupacji). Dość niejasno przedstawia się $\mathrm{w}$ analizowanych książkach obrona i kapitulacja

9 We wprowadzeniu do rozdziału o początku wojny w Europie Zachodniej w jednym z podręczników znalazło się miejsce na sarkastyczne stwierdzenie, że „wiosną 1939 roku w prasie francuskiej pojawiło się hasło Nie chcemy umierać za Gdańsk. Rok później okazało się, że Francuzi nie chcą umierać też za Paryż” [PL-SOP1]. Dla kontrastu kilka stron dalej (s. 89) w podsumowaniu działań zbrojnych w Europie przed niemiecką agresją na ZSRR znajduje się polecenie uzasadnienia błędności stwierdzenia, że Polacy we wrześniu 1939 r. nie chcieli walczyć.

${ }^{10}$ Autorzy książki przedstawiają bitwę pod Tomaszowem jako stoczoną z Niemcami. Wspominają o wyróżniającym się tam generale Andersie [PL-SOP2].

${ }^{11}$ O Katyniu (liczbie ofiar, wersji radzieckiej) piszą też w nawiązaniu do wydarzeń września 1939 r. podręczniki rosyjskie [RUS-7 i 8]. Nie analizuję tu bliżej tego zagadnienia jako nieodnoszącego się bezpośrednio do kampanii wrześniowej. 
Lwowa. Wydaje się, że poświęcenie jej więcej niż jednego zdania ułatwiłoby uczniom zrozumienie przebiegu wydarzeń.

Tak jak w podręcznikach zagranicznych, kampania wrześniowa (autorzy podręcznika Nowej Ery piszą także o kampanii polskiej i tak właśnie tytułują rozdział [PL-NE]; kampania polska pojawia się też w PL-SOP1) jest przedstawiana jako realizacja niemieckiego planu wojny błyskawicznej. Definiując ten rodzaj wojny, jedne podręczniki koncentrują się raczej na ogólnej strategii - wykorzystania zdobyczy techniki (broni pancernej, lotnictwa) do szybkiego uderzenia na przeciwnika [PL-Stentor; PL-SOP1; PL-SOP2] - inne wchodzą w szczegóły taktyczne, opisując kolejne fazy rozbijania wrogiej armii (piechota, artyleria i lotnictwo, czołgi) jako istotę tej wojny [PL-WSiP; PL-NE; PL-WSzPWN]. W jednym przypadku charakterystyce Blitzkriegu towarzyszy stosowna infografika [PL-WSiP].

Szata graficzna polskich podręczników już od pewnego czasu nie odbiega od standardów światowych, z wszelkimi tego zaletami i wadami. Książki są bogato ilustrowane, a teksty - mocno ustrukturyzowane. Pojawiają się wspomniane infografiki, wyróżnione graficznie (kolorem tła, ramką, czcionką) kapsuły, noty biograficzne, ciekawostki, polecenia. Naturalnie, ogranicza to objętość i rozbija spójność tekstu autorskiego.

Jeśli chodzi o fotografie, trudno mówić o konkretnym kanonie, choć chyba można odnotować, że tak typowe dla wcześniejszych opracowań zdjęcie żołnierzy niemieckich łamiących polski szlaban graniczny znajdziemy już tylko w jednym podręczniku [PL-SOP2], z zaznaczeniem, że to pozowana fotografia propagandowa. Dość powszechnie występują natomiast kapitulujący obrońcy Poczty Polskiej w Gdańsku [PL-NE; PL-SOP1], pancernik Schleswig-Holstein [PL-WSiP; PL-Stentor; PL-NE] i walki w Warszawie [PL-SOP2; PL-WSiP; PL-Stentor - płonący Zamek Królewski; PL-WSzPWN - uciekająca z Warszawy ludność cywilna; PL-SOP1 - ludność Warszawy z interesującym poleceniem określenia przeżyć pokazanych osób]. Pojawiają się przejawy współpracy radziecko-niemieckiej: albo wspólna defilada w Brześciu [PL-WSzPWN], albo uścisk dłoni żołnierzy obu stron [PL-WSiP; PL-SOP2]. Znajdziemy także zdjęcia niektórych przywódców walk - co, jak wiadomo, przybliża ich postacie uczniom. 
Chyba najpowszechniej, najobszerniej i najżyczliwiej książki przedstawiają osobę Stefana Starzyńskiego. Często poświęcają mu osobny biogram. W podręczniku Wydawnictwa Stentor wymienia się przedwojenne osiągnięcia prezydenta Warszawy, jego decyzję o pozostaniu w mieście mimo ewakuacji władz państwowych i wojenne losy ${ }^{12}$ [PL-Stentor]. Korzystne oceny zbierają także generał Tadeusz Kutrzeba, kapitan Władysław Raginis oraz pułkownik Franciszek Kleeberg - rzadko jednak informacje o nich wychodzą poza nazwisko [PL-WSzPWN zamieszcza kapsuła o pułkowniku Kleebergu; PL-SOP2 - jego fotografię].

Najbardziej kontrowersyjna - co chyba naturalne - jest postać marszałka Edwarda Rydza-Śmigłego, choć tak jak i we wcześniejszych podręcznikach autorzy mocno się różnią w jego prezentacji. Zdecydowanie najbardziej krytyczny jest podręcznik Wydawnictw Szkolnych i Pedagogicznych, w którym jest mowa o „powszechnym potępieniu” Rydza przez społeczeństwo za ewakuację władz do Rumunii („Oczekiwano, że marszałek raczej polegnie w walce lub popełni samobójstwo” [PL-WSiP, s. 156-157'13] powstaje jednak pytanie, w jaki sposób zbadano te oczekiwania) i o tym, że niewypowiedzenie wojny Związkowi Radzieckiemu przez prezydenta Ignacego Mościckiego „do dzisiaj część historyków uważa za poważny błąd” (s. 157). Podobnego zdania są autorzy podręcznika Nowej Ery, gdzie czytamy, że decyzja marszałka o unikaniu walk z Armią Czerwoną „okazała się dużym błędem politycznym" [PL-NE], jeśli natomiast chodzi o decyzję o ewakuacji, to autorzy tej książki proponują, by uczniowie sami ją ocenili, a dodatkowo podają listę lektur uzupełniających.

W ten sposób widzimy, jak różnie podręczniki mogą podchodzić do kwestii kontrowersyjnych. Po pierwsze, autorzy mogą po prostu zająć stanowisko i przedstawić swoją jednoznaczną ocenę. Po drugie, mogą powołać się na autorytet „historyków”, aczkolwiek stwierdzenie o „części history-

${ }^{12}$ Co ciekawe, niekiedy opisywane są wojenne losy Starzyńskiego aż do śmierci w Dachau w 1943 r. [PL-NE; PL-Stentor], ale w książce sygnowanej przez WSiP stwierdza się jedynie, że Starzyński po kapitulacji Warszawy został „aresztowany przez Niemców i zamordowany w nieznanych okolicznościach”, a w biogramie podaje datę śmierci jako „1944?” [PL-WSiP].

${ }^{13} \mathrm{~W}$ innym podręczniku wspomina się samobójstwo kapitana Raginisa jako bohaterski wyczyn [PL-Stentor]. 
ków” ten autorytet nieco podważa - bo część to nie wszyscy, a zatem inna grupa profesjonalistów zapewne nie podziela tego zdania. $Z$ jednej strony uczniowie uświadamiają sobie, że mają do czynienia z wydarzeniem kontrowersyjnym i że historycy mogą różnić się w swoich poglądach na przeszłość. Z drugiej strony cytowane zdanie sugeruje (czy aby słusznie?), że rolą historyków jest oceniać poprawność podejmowanych w przeszłości działań. Bardziej przypadło mi do gustu - jako wierniej oddające istotę tej profesji - stwierdzenie z podręcznika wydanego przez Stowarzyszenie Oświatowców Polskich, że wśród historyków do dziś toczą się dyskusje o przyczynach klęski Polski [PL-SOP2] ${ }^{14}$. Po trzecie wreszcie, można zachęcić uczniów do zajmowania własnego stanowiska - najlepiej dając im do tego stosowną pożywkę: literaturę przedmiotu lub tekst źródłowy.

Teksty źródłowe częściej dotyczą wojny z ZSRR niż z Niemcami. Częściej - i dobrze - są to relacje osobiste albo prasa niż dokumenty urzędowe. Co ciekawe, nie pojawia się tak powszechnie cytowane dawniej przemówienie Stefana Starzyńskiego o wielkiej Warszawie. Tylko w tytule kapsuły z biogramem Starzyńskiego czytamy „Chciałem, by Warszawa była wielka” [PL-Stentor] (ale dalszego ciągu nie ma). W innym podręczniku zostało przytoczone orędzie prezydenta Mościckiego z 1 września [PL-SOP2]. Lista źródeł dotyczących wydarzeń z 17 września jest dłuższa. Spotykamy bowiem radziecki tekst propagandowy skierowany do mieszkańców wschodnich obszarów Rzeczypospolitej z dobrym poleceniem, by zwrócić uwagę na jego słownictwo i styl [PL-Stentor]. Ten sam podręcznik publikuje artykuł z lwowskiego „Dziennika Polskiego” na temat reakcji angielskich i francuskich na wydarzenia z 17 września - chyba niezbyt szczęśliwie wybrany, jako że ustalenie, które informacje pochodzą z pierwszej, drugiej i dalszych rąk nie jest łatwe (gazeta jest lwowska, przytacza informacje prasy francuskiej, notę rządów Francji i Wielkiej Brytanii za radiem wi-

${ }^{14}$ Skoro wróciliśmy do warsztatu historyka, to zgrzytem w na ogół rzeczowym tekście jest zdanie: „Wpływ na decyzję Rumunów mogła mieć m.in. Francja. Paryż był bowiem zainteresowany objęciem władzy w Polsce przez koła profrancuskie z gen. Władysławem Sikorskim na czele" [PL-NE, s. 127]. Po pierwsze, przedstawione jako czysta spekulacja, bez podstaw źródłowych, raczej jak ustalenia detektywistyczne. Po drugie, skoro występuje skrót m.in., to wypadałoby przytoczyć inne możliwe uwarunkowania decyzji. Po trzecie, czy można w tej sytuacji mówić o objęciu władzy w Polsce? 
leńskim, stanowisko rządu polskiego wyrażone przez ambasadora Edwarda Raczyńskiego za rozgłośnią londyńską, przywołuje wreszcie paryski „Le Jour" do spekulacji o wschodniej polityce Hitlera), a polecenia do tekstu wcale nie zwracają na to uwagi. W książkach Stowarzyszenia Oświatowców cytuje się notę rządu ZSRR, skierowaną do ambasadora RP w Moskwie, polecając wyłuskać z niej radzieckie usprawiedliwienie agresji na Polskę [PL-SOP2; PL-SOP1]. Ten ostatni podręcznik zamieszcza także źródłowy radziecki plakat do analizy (z dobrym poleceniem zidentyfikowania przedstawionych postaci i symboli).

$\mathrm{Na}$ uznanie zasługuje bardzo emocjonalna relacja córki o rozstrzelaniu jej ojca, powstańca śląskiego, przez Niemców - to jeden z nielicznych momentów, gdzie w narracji poświęconej kampanii wrześniowej wyraźnie pojawiają się emocje [PL-NE] ${ }^{15}$. Poza tym mamy do czynienia z przekazem mocno faktograficznym, gdzie dominuje historia polityczno-militarna, a wątki społeczne, tzw. pierwiastek ludzki, występują gdzieś na dalekim planie. Nie mamy ani specjalnego okrucieństwa najeźdźców, ani bogatego wachlarza emocji towarzyszących na pewno ludności cywilnej. Między wierszami można je wyczytać z biogramu Stefana Starzyńskiego, który „opanował panikę w mieście [Warszawie]” [PL-NE] albo ze stwierdzeń o bohaterstwie Polaków przegrywającym z niemiecką techniką wojenną.

Nic się nie zmieniło, jeśli chodzi o anonimowość najeźdźców. Na kartach książek pojawia się tylko jeden wymieniony z imienia i nazwiska wojskowy niemiecki, generał Heinz Guderian: raz w tekście dodatkowym o bitwie nad Wizną [PL-Stentor], raz zaś mimochodem jako twórca koncepcji Blitzkrieg [PL-NE]. Nie ma natomiast żadnych dowódców radzieckich - ani w zasadzie szeregowych żołnierzy. Do wyjątków należy zdanie:

żołnierze Armii Czerwonej mieli do Polaków stosunek niejednolity, od deklaracji obrony do aresztowań i rozstrzeliwania [PL-SOP2]

${ }^{15} \mathrm{O}$ roli emocji w nauczaniu historii m.in. T.E.A.C.H. Teaching Emotional and Controversial History 3-19. A report from the Historical Association on the challenges and opportunities for teaching emotive and controversial history 3-19, London 2007, s. 4-5. 
oraz relacja anonimowego czołgisty niemieckiego z walk w Warszawie w [PL-WSiP]. Są tylko armie, formacje wojskowe, oddziały - wrogowie realizujący plany polityczne i militarne swoich władz [PL-SOP2: „Faszystowskie Niemcy zrealizowały swe odwetowe i zaborcze dążenia”].

Ale na dobrą sprawę również polskim bohaterom brakuje człowieczeństwa, to „postaci historyczne”, ale nie osoby. Postaci pomnikowe, odizolowane od rzeczywistości. Organizują działania, dokonują czynów, decyzje raczej ogłaszają, niż podejmują; nie wątpią, nie wahają się, nie zasięgają porad. Nie widzimy więc ludzi stających w obliczu sytuacji kryzysowej, z którą na miarę sił i możliwości próbują sobie radzić. Na koniec są obiektami oceny ${ }^{16}$, ale nie empatii. Obawiam się, że takie podejście uczniowie mogą przenosić również na dzisiejszych polityków i szerzej - ludzi podejmujących decyzje, nieokreślonych „onych”.

$\mathrm{Na}$ koniec - o bilansie walk, przyczynach klęski i konsekwencjach kampanii wrześniowej. Powszechnie przytaczane są dane liczbowe dotyczące sił militarnych walczących stron. Czasami są one ograniczane wojsk polskich i niemieckich, z podziałem na żołnierzy, działa, czołgi i samoloty [PL-SOP1; PL-SOP2]. W innym miejscu włączane bywają jeszcze wojska radzieckie [PL-WSiP; PL-Stentor; PL-WSzPWN]. Diagramy słupkowe zamieszczone w podręczniku Wydawnictwa Stentor zdecydowanie sprzyjają zobrazowaniu i zapamiętaniu przytaczanych liczb, które powinny stanowić podstawę do dyskusji o przyczynach klęski Rzeczypospolitej [PL-Stentor] - o czym niżej. Podręczniki przytaczają także na ogółbilans strat, czasem zaznaczając, że są to dane szacunkowe [PL-WSzPWN; PL-SOP1 i PL-SOP2: niektóre liczby poprzedza słowo „około”]. Nie wnikają wprawdzie w sposoby przeprowadzenia owych szacunków, ale pokazują, że dane liczbowe mogą być przedmiotem ustaleń, uściśleń, że nie muszą być do końca jednoznaczne - jeszcze jeden element kuchni historyka.

W przeciwieństwie do książek zagranicznych, z których tylko jedna rosyjska zamieszcza zdjęcie polskiej kawalerii z podpisem „Polska kawaleria szykuje się do ataku” [RUS-2], w książkach polskich wciąż powraca kwe-

${ }^{16}$ Np. „Pobita Armia «Łódź» rozpoczęła chaotyczny odwrót, spotęgowany opuszczeniem jej przez dowódcę. Mająca wspierać ją Armia «Prusy», fatalnie dowodzona, a wkrótce porzucona przez gen. Stefana Dęba-Biernackiego [...]” [PL-WSiP, s. 154]. 
stia udziału polskiej konnicy w wojnie błyskawicznej. W jednej z nich zamieszczono w związku z bitwą nad Bzurą fotografię oddziału konnego przejeżdżającego przez Sochaczew bez żadnego komentarza [PL-SOP2] (oby nauczyciel stanął na wysokości zadania!). Inna wprost polemizuje z komunistyczną propagandą na ten temat, przekonując o skuteczności działań kawalerii i przytaczając konkretne przykłady - a tekst jest ilustrowany obrazem Michała Byliny [PL-WSiP]. Wreszcie Stentor przekazuje pałeczkę uczniom ( $\mathrm{a} \mathrm{w}$ praktyce zapewne nauczycielowi), autorzy na marginesie analizy źródła: świadectwa ukończenia szkoły podoficerskiej Mazowieckiej Brygady Kawalerii przez jednego z uczestników kampanii wrześniowej pytają bowiem, ,jaką rolę mogły odgrywać oddziały kawalerii w dobie rozwoju wojsk pancernych" [PL-Stentor].

Przyczyny klęski i ocena szans zwycięstwa nierzadko przenoszone są do własnych rozważań i dyskusji uczniów [PL-SOP1; PL-Stentor: tu w formie forum dyskusyjnego: „Wojna obronna, czyli polski wrzesień czy były szanse?”]. Jak wspomniano, zaznacza się, że są one przedmiotem kontrowersji. Znaczenie kampanii wrześniowej ogranicza się w zasadzie tylko do umiędzynarodowienia konfliktu z Niemcami. Sporadycznie mowa o rozbiorze Polski [PL-Stentor - „kolejnym”]. Pada także propozycja, by uczniowie podjęli się oceny, „nie tylko pod względem militarnym”, kilku kluczowych wydarzeń z kampanii [PL-SOP2].

Podkreśla się, że mimo przegranej kampanii wrześniowej państwo polskie funkcjonowało, a Polska pozostała stroną walczącą [PL-Stentor; PL-WSzPWN; PL-SOP1; PL-SOP2]. Nie jest natomiast poruszane militarne znaczenie działań w Polsce (np. strat niemieckich) ani kwestie psychologii czy pamięci zbiorowej.

\section{Wnioski}

Wydaje się, że - tak jak i przy różnych innych tematach ${ }^{17}$ - polskie podręczniki zawierają sporo materiałów i pomysłów dydaktycznych. Trudno

${ }^{17}$ Ostatnio pisałam o tym w odniesieniu do stanu wojennego: J. Wojdon, Jak (można) uczyć o stanie wojennym, „Wiadomości Historyczne” 2012, nr 6, s. 36-42. 
jednak wskazać książkę jedyną, najlepszą, uniwersalną. Optymalne wydaje się rozwiązanie, w którym nauczyciel dysponuje jak największą liczbą dostępnych na rynku pozycji i wybiera z nich różne elementy do wykorzystania w pracy ze swoimi uczniami.

Jeśli zaś chodzi o podręczniki zagraniczne, to popieram kilkakrotnie zgłaszane postulaty Adama Suchońskiego ${ }^{18}$, by polscy badacze bardziej aktywnie przedstawiali w językach kongresowych swoje ustalenia, z których ich zagraniczni koledzy mogliby czerpać wiadomości, a także apel o osobiste kontakty polskich uczonych z autorami i/lub recenzentami zagranicznych podręczników (w tym polskich i zagranicznych dydaktyków historii) - historię bowiem nie tylko tworzą ludzie, ale także piszą ludzie. Warto wreszcie samemu czerpać z dorobku zagranicznego, aby był dla nas on nie tylko przedmiotem oceny, lecz także źródłem inspiracji.

\section{Wykorzystane podręczniki:}

Austria:

A-1: H. Franzmair, Zeitzeichen: Wirtschafts- und Sozialgeschichte 3, Trauner, Linz 2006, s. 304-305.

Chorwacja:

HR-1: M. Kolar-Dimitrijević et al., Povijest, t. 8, Meridijani, Samobor 2007, s. 101-102.

HR-2: S. Koren, Povijest: udžbenik za 8. razred osnovne škole, Profil, Zagreb 2007, s. 104-110.

Czechy:

CS-1: P. Bělina, Dějiny evropské civilizace, Paseka, Praha 1999, s. 226-227. CS-2: F. Čapka, Dějepis, t. 9: Od roku 1918 do současnosti, Scientia, Praha 2007, s. 70-71.

18 A. Suchoński, Wrzesień 1939 roku, s. 400; idem, Czy istnieje Polska w świecie, „Wiedza i Życie” 2001, nr 9; Prof. Suchoński do MSZ: Obraz Polski w Europie fatalny, „Gazeta. Opole” 18 sierpnia 2011, http://opole.gazeta.pl/opole/1,35114,10132166,Prof_ Suchonski_do_MSZ_Obraz_Polski_w_Europie_fatalny.html (dostęp: 22.11.2013). 
CS-3: J. i J. Kuklik, Nejnovějšsi dèjiny, SPN, Praha 2002, s. 63-64.

CS-4: R. Kvaček, České dějiny 2: učebnice pro střední školy, SPL-Práce [u.a.], Praha 2002, s. 154.

CS-5: H. Mandelová et al., Dějiny 20. století, Dialog, Liberec 2005, s. 52$-56,70-71$.

Francja:

F-1: T. Gasnier, Histoire 1, Bréal, Rosny-sous-Bois 2007, s. 303-305.

F-2: Histoire 2. L' Europe et le monde du congrès de Vienne à 1945: Premières

$L, E S$, S, ed. P. Geiss, D. Henri, G. LeQuintrec, Nathan \& Klett, Paris- Stuttgart 2008, s. 298-306.

Hiszpania:

E-1: Historia del mundo contemporáneo: bachillerato 1; Andalucía, ed. J. M. R. Ramblado, Algaida, Sevilla 2005, s. 291.

Holandia:

NL-1 Feniks: geschiedenis voor de onderbouw, red. L. Salemink, J. Venner Utrecht, t. 3, ThiemeMeulenhoff, Zutphen 2009, s. 92-93, 98-99.

Finlandia:

SF-1: E. Heikkonen, M. Ojakoski, J. Väisänen, Lukion historia. Muutosten maailma. Kansainvälisetsuhteet, t. 3, Werner Söderström Osakeyhtiö, Helsinki 2007, s. 81.

Irlandia:

IRL-1: L. Dermont, The past today: complete junior certificate history, Gill \& Macmillan, Dublin 2002, s. 378-379.

IRL-2: D. O'Leary, History revision notes for leaving certificate, Gill \& Macmillan, Dublin 2000, s. 187-188.

Litwa:

LT-1: I. Kapleris, Laikas 10, Briedis, Vilnius 2007, s. 78-85. 
Łotwa:

LV-1: S. Goldmane, Jaunākie laiki: mācibu grāmata, Zvaigzne ABC, Rīgā 2006, s. 82-83.

Niemcy:

D-1: Geschichte konkret, hrsg. H.-J. Pandel, Bd. 4, Schroedel, Braunschweig 2007, s. 123-124.

D-2: Kursbuch Geschichte: von der Antike bis zur Gegenwart, hrsg. K. Laschewski-Müller, R. Rauh, Volk-und-Wissen, Cornelsen, Berlin 2009, s. 445, 449.

D-3: Oldenbourg-Geschichte für Gymnasien 13, hrsg. M. Treml, Oldenbourg, München 1994, s. 24-25.

D-4: Zeiten und Menschen 4, hrsg. H.-J. Lendzian, W. Mattes, Schöningh, Paderborn 2002, s. 136-137.

Rosja:

RUS-1: $\Lambda$. Н. Алексашкина et al., Россия и мир в ХХ веке. Учебник для 11 класса, Просвещение, Москва 2006, s. 181.

RUS-2: A. А. Кредер, Новейшая история зарубенных стран. Учебник для основной школь [9-й кл.], Центр гуманитарного образования, Московские учебники, Москва 2005, s. 158-162.

RUS-3: A. A. Аанилов еt al., История России. XX - начало XXI века. Учебник для9 класса общеобразовательных учреждений, Просвещение, Москва 2007, s. 206.

RUS-4: Н. В. Загладин, Новейшая история зарубежнылх стран. ХХ век. Учебник. 9 класс, Русское Слово, Москва 2006, s. 90-92.

RUS-5: Н. В. Загладин, Всемирная история. ХХ век. Учебник. 11 класс, Русское Слово, Москва 2005, s. 150.

RUS-6: Н. В. ЗаглаАин et al., История Отечества. XX - начало XXI века. Учебник. 11 класс, Русское Слово, Москва 2005, s. 211-212.

RUS-7: Н. В. Загладин, История России и мира в ХХ веке. Учебник. 11 класс, Русское Слово, Москва 2005, 180-182, 184-185.

RUS-8: Н. В. ЗаглаАин etal., История Отечества. ХХ век. Учебник. 9 класс, Русское Слово, Москва 2003, s. 174. 
Rumunia:

RO-1: Istorie. Universală modernă şi contemporană. Manual pentru clasa a 11-a, ed. O. Bozgan, Ed. ProGnosis, Bucureşti [2003], s. 142-147 .

Serbia:

SR-1: S. Rajić et al., Istorija, t. 8, Zavod za Udžbenike i Nastavna Sredstva, Beograd 2005, s. 125-128.

USA:

USA-1: J. A. Banks, Our world, National Geographic; Macmillan, McGrawHill, New York, NY-Washington, D.C. 2003, s. 556.

USA-2: F. K. Cox et al., Human Heritage: a world history, Glencoe, McGrawHill, New York, NY 2006, s. 615-616.

USA-3: E. G. Ellis et al., The modern era, Prentice Hall, Upper Saddle River, NJ 2005, s. 466, 472-473.

USA-4: M. A. Farah, A. B. Karls, World history: the human experience, Glencoe, McGraw-Hill, New York, NY 2000, s. 824, 831.

USA-5: M. B. Norton, A people and a nation: a history of the United States, Houghton Mifflin, Boston 2003, s. 463-464.

Wielka Brytania:

GB-1: M. Collier, Ph. Pedley, Germany 1919-45, Heinemann, Oxford 2000, s. 238-239.

GB-2: M. Collier et al., Hitler and the Nazi State, Heinemann, Oxford 2005, s. 83, 102, 121.

GB-3: J. Jenkins, E. Feuchtwanger, Hitler's Germany, Murray, London 2003, s. 130-148.

GB-4: N. Kelly, G. Lacey, Modern world history: syllabus 1607, Heinemann, Oxford 1999, s. 74-77.

GB-5: J. A. Kerr, The growth of nationalism in Germany, 1815-1939, appeasement and the road to war, 1933-1939, Leckie \& Leckie, St. Andrews 2005, s. 95.

GB-6: J. Kidd et al., Heinemann history scheme, book 3: Into the twentieth century, Heinemann, Oxford 2001, s. 150. 
GB-7: F. MacDonough et al., Conflict, communism and fascism: Europe 1890-1945, Cambridge Univ. Press, Cambridge 2001, s. 103-112.

GB-8: S. Ross, Causes and consequences of the Second World War, Evans, London 2003, s. 28-30, 75.

GB-9: W. Simpson, Hitler and Germany, Cambridge University Press, Cambridge 2004, s. 112.

Włochy:

I-1: A. Aruffo et al., Lo scontro per la supremazia mondiale, Cappelli, Bologna 1998, s. 217, 228.

I-2: V. Calvani et al., Il Novecento, Mondadori Scuola, Milano 1999, s. $162-163$.

I-3: E. Garellis et al., Il Novecento, Petrini, Torino 1998, s. 125-128.

Polska:

PL-NE, S. Roszak, J. Kłaczkow, Poznać przesztość. Wiek XX. Podręcznik do historii dla szkót ponadgimnazjalnych. Zakres podstawowy, Nowa Era, Warszawa 2012, s. 124-131.

PL-SOP1: S. Zając, Teraz historia - podręcznik dla szkoty ponadgimnazjalnej. Zakres podstawowy, Stowarzyszenie Oświatowców Polskich, Toruń 2012, s. 80-84 i 89.

PL-SOP2: Z. Kozłowska, I. Unger, S. Zając, Poznajemy przeszłość-podręcznik dla szkoty ponadgimnazjalnej. Zakres podstawowy, Stowarzyszenie Oświatowców Polskich, Toruń 2012, s. 113-119.

PL-Stentor: A. Brzozowski, G. Szczepański, Ku wspótczesności. Dzieje najnowsze 1918-2006. Podręcznik dla klasy I szkót ponadgimnazjalnych. Zakres podstawowy, Stentor, Warszawa 2012, s. 115-125.

PL-WSiP: R. Dolecki, K. Gutowski, J. Smoleński, Po prostu historia. Szkoty ponadgimnazjalne. Zakres podstawowy, Wydawnictwa Szkolne i Pedagogiczne, Warszawa 2012, s. 150-160.

PL-WSzPWN: D. Stola, Historia. Wiek XX. Podręcznik. Szkoty ponadgimnazjalne. Zakres podstawowy, Wydawnictwo Szkolne PWN, Warszawa 2012, s. 62-65. 


\title{
The Polish September Campaign of 1939 in Polish and foreign school textbooks
}

\author{
(SUMMARY)
}

The article discusses the ways how the Polish campaign of 1939 is presented in Polish and foreign (European) textbooks. In case of the foreign textbooks it is stressed that the German attack on Poland on $1^{\text {st }}$ of September, 1939 is always mentioned as the beginning of WWII. Other events of the campaign are enumerated and comments presented in textbooks are cited, with special attention paid to the British and French declaration of war, the Soviet attack on Poland on Sept. $17^{\text {th }}, 1939$ and the end of the military campaign. Elements common for different textbooks from different countries are identified as well as textbooks that are significantly different (e.g. some Russian interpretations). In case of the Polish textbooks, new approaches (as compared to the old editions) are noticed, balance about the presentation of facts and interpretations is discussed, personalities of individual commanders presented. Non-textual elements, e.g. maps, photographs, diagrams are analyzed, alongside with primary sources included into the chapters, tasks set for pupils and other materials. The issues of multiperspectivity and emotions in teaching history are addressed.

Joanna Wojdon

Instytut Historyczny, Uniwersytet Wrocławski joanna.wojdon@uni.wroc.pl 